\title{
Global timber investments and trends, 2005-2011
}

Frederick Cubbage ${ }^{1 *}$, Patricio Mac Donagh ${ }^{2}$, Gustavo Balmelli ${ }^{3}$, Virginia Morales Olmos ${ }^{4}$, Adriana Bussoni ${ }^{5}$, Rafael Rubilar ${ }^{6}$, Rafael De La Torre ${ }^{7}$, Roger Lord ${ }^{8}$, Jin Huang ${ }^{9}$, Vitor Afonso Hoeflich ${ }^{10}$, Mauro Murara ${ }^{11}$, Bruno Kanieski ${ }^{12}$, Peter Hall ${ }^{13}$, Richard Yao ${ }^{13}$, Paul Adams ${ }^{14}$, Heyns Kotze $^{15}$, Elizabeth Monges ${ }^{16}$, Carmelo Hernández Pérez $^{17}$, Jeff Wikle ${ }^{18}$, Robert Abt ${ }^{19}$, Ronalds Gonzalez ${ }^{19}$, Omar Carrero ${ }^{19}$

From Third International Congress on Planted Forests

Bordeaux, France; Dublin, Ireland; and Porto and Estoril, Portugal. 16-21 May 2013

\begin{abstract}
Background: Prior research in 2005 and 2008 estimated planted forest investment returns for a set of countries and included some natural forest species in a few countries. This research has extended those analyses to a larger set of countries and focused on plantation species, for seven years. This research serves as a "benchmarking" exercise that helps identify comparative advantages among countries for timber investment returns, as well as other institutional, forestry, and policy factors that affect investments. Furthermore, it extends the analyses to examine the effects of land prices, environmental regulations, and increased productivity on timber investment returns, as well as comparing timber returns with traditional stock market returns.
\end{abstract}

Methods: We estimated financial returns in 2005, 2008, and 2011 for a range of global timber plantation species and countries, using net present value (NPV), internal rate of return (IRR), and Land Expectation Value (LEV)-or the Faustmann Formula-as criteria. Per the Faustmann approach, we excluded land costs initially, using a common real discount rate of $8 \%$ for all species in all countries to make equivalent comparisons.

Results: Returns for exotic plantations in almost all of South America-Brazil, Argentina, Uruguay, Chile, Colombia, Venezuela, and Paraguay-were substantial, as well as in China. In 2011, returns for Eucalyptus species were generally greater than those for Pinus species in each country, with most having IRRs of $14 \%$ per year or more. The IRRs for Pinus species in South America were slightly less, ranging from 8\% to 12\%, except for Brazil, where they were $19 \%$ to $23 \%$. Internal rates of return ranged from $5 \%$ to $12 \%$ for plantations of coniferous or deciduous species in China, South Africa, New Zealand, Australia, Mexico, and the United States. Although lower than returns from South America, these would still be attractive to forest investors. Land costs and environmental regulations reduced plantation investment returns for all the countries studied, but the largest reductions were observed in South America. However, net returns these remained greater than for plantations in temperate forests.

Conclusions: Trend analyses indicated that Brazil had the greatest increase in timber investment returns during the period examined; returns in other southern hemisphere countries remained fairly stable; and the US South had substantial decreases in returns. New Zealand, Australia, the United States, Chile, and Mexico had the best rankings regarding risk from political, commercial, or government actions and for the ease of doing business. Conversely, Venezuela, Colombia, and Argentina had high risk ratings, and Brazil and Venezuela were ranked as more difficult countries for ease of business. Recent government actions in several countries in South America, except Colombia,

\footnotetext{
* Correspondence: fredcubbage@yahoo.com

${ }^{1}$ Fred Cubbage, Professor, Forestry and Environmental Resources, North

Carolina State University, Raleigh, NC 27695-8008, USA

Full list of author information is available at the end of the article
}

(C) 2014 Cubbage et al.; licensee Springer. This is an Open Access article distributed under the terms of the Creative Commons Attribution License (http://creativecommons.org/licenses/by/4.0), which permits unrestricted use, distribution, and reproduction in any medium, provided the original work is properly cited. 


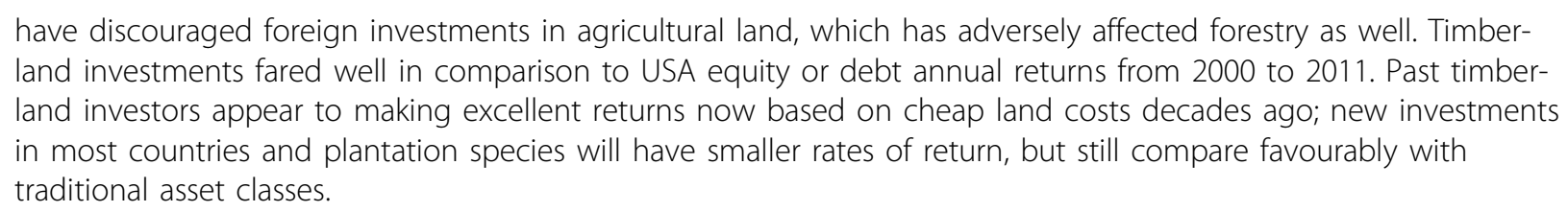

\section{Introduction}

Planted forests provide timber for wood products and trees for conservation purposes. The Food and Agriculture Organization (FAO) (2007) termed production forests as those that produce commercial and industrial roundwood for manufacturing purposes, and conservation forests as those with primary purposes for soil restoration, water protection, climate amelioration, windbreaks, or environmental purposes other than wood production. Planted forests include fast grown plantations as well as large areas of planted trees of native species, particularly in the northern hemisphere. They comprise a total of about 264 million ha, $6.5 \%$ of the world's total forest area of 4.033 billion ha (FAO 2011).

Based on the 2005 definition, the FAO (2007) estimated that there were 110 million ha of production plantations$79 \%$ of all plantations-and 30 million ha of conservation plantations $-21 \%$ of the total of 140 million ha. Carle and Holmgren (2006) estimated that planted forests could already provide about two thirds of the world's total industrial roundwood furnish based on their amount of annual timber growth. Planted forests (both exotic and native) clearly are becoming increasingly important for industrial roundwood in the traditional northern temperate countries as well as in the subtropics and tropics. Favourable financial analyses of forest plantations underpin a large proportion of these investments, both in maintaining productive forest land in existing locations, and expanding forestry investments in new regions.

Prior research in 2005 and 2008 (Cubbage et al. 2007, 2010) estimated timber investment returns for a smaller set of countries than the present work, and included some natural forest species in a few countries. This research has extended those analyses to a larger set of countries and focused on plantation species. As a result, it provides a means to compare trends in prospective plantation investment returns over the seven years. This research serves as a "benchmarking" exercise that helps identify comparative advantages among countries for timber investment returns, as well as other institutional, forestry, and policy factors that affect investments. Furthermore, it extends the analyses to examine the effects of land prices, environmental regulations, and increased productivity on timber investment returns, as well as comparing timber returns with traditional stock market returns. The results of our prior research are summarised briefly here as part of a trend analysis in the results section.

Binkley (1997) and Sedjo and Botkin (1997) state that plantations will decrease pressure on the harvest of natural forests, noting that the high growth rates can supply an increasing proportion of the world's wood fibre needs, both for domestic production and for export. Sedjo (2001) summarised data on average plantation internal rates of return (IRRs) in the 1990s. The growth rates at that time were generally less than $30 \mathrm{~m}^{3} / \mathrm{ha} / \mathrm{yr}$ except for Eucalyptus spp. He found that IRRs in the southern hemisphere were significantly greater than those in the northern hemisphere, with IRRs of more than 15\% in Chile, South Africa, and Brazil. Internal rates of return in the USA and New Zealand were slightly less, at 7\% to $13 \%$, and Europe was much less, at 5.6\%. Pulpwood and saw-timber rates of return were generally comparable and, in several cases, pulpwood IRRs were greater.

Recent research has focused on the merits of forestry investments versus traditional stock and bond assets, especially for large institutional investors. Generally this research has found that forestry investments have returns that are about the same or slightly lower than traditional asset classes. They also have superior riskadjusted returns, with less risk than comparable stock assets. And they also can contribute well to a diversified investment portfolio, since their returns are either inversely correlated or not correlated with stock market performance (Redmond and Cubbage 1988, Cascio and Clutter 2008, Mei and Clutter 2010).

Cascio and Clutter (2008) found that, from 1987 to 2005, timber returns as reported in the US National Council of Real Estate Investment Fiduciaries (NCREIF) Timberland Index-which includes timber and land components-had average annual returns of $11 \%$ in the US South and 22\% in the West, with standard deviations of $6 \%$ and $23 \%$ respectively. They also developed a synthetic South-wide timber series for the same period, which yielded average returns per state ranging from $7 \%$ to $13 \%$. However, timber-land investment returns have decreased since this peak period, as have stock market returns.

This research examined timber investment returns, policy factors, and risks as of 2011. The objectives of this project were to: (1) estimate comparative timber investment returns, not including land costs, for important forest species and countries throughout the world; 
(2) synthesise quantifiable literature on risks among those countries; (3) estimate the effects of land costs, environmental regulations and forest productivity on the base returns for selected countries in the Americas; (4) examine the trends in these forest and plantation returns over time; and (5) compare those timber investment returns with traditional equity and debt investment returns of stocks and bonds.

\section{Methods}

The co-authors cooperated in this research by identifying the most important forest species in their countries, and collecting forest productivity and cost data to estimate returns to timber investments at the stand or forest management unit level. These costs include all relevant forest regeneration, intermediate stand treatments and management, and an equal fixed cost for taxes and administration for every country and stand.

We estimated productivities based on using a common Mean Annual Increment (MAI) for growth rates for typical or representative stands for each species in the relevant region of the country. Then we estimated typical costs for establishment, stand management, administration, or other factors for each species/region. Similarly, relevant information on timber prices by product size was gathered from available literature or personal contacts with colleagues in the timber sector. Published timber price and management cost series are only available for a few countries, such as the Timber Mart-South and a Forest Landowner series in the USA. Consequently, most of the input costs and timber prices were obtained by each co-author in their relevant country by making personal contacts with foresters in that country. These data were then used to calculate timber investment returns for forest landowners based on typical forest management regimes, input costs, timber prices, and rotations.

Discounted cash flow analyses and capital budgeting criteria were used to evaluate timber investment returns, including net present value (NPV), land expectation value (LEV)-or the Faustmann formula-and internal rate of return (IRR), such as described in Wagner (2012) and Klemperer (2003). The respective formulas follow:

$$
\begin{aligned}
& \mathrm{NPV}=\sum_{n=0}^{N} B_{\mathrm{n}} /(1+\mathrm{i})^{\mathrm{n}}-\sum_{n=0}^{N} C_{\mathrm{n}} /(1+\mathrm{i})^{\mathrm{n}} \\
& \mathrm{LEV}=\mathrm{NPV}+\left(\mathrm{NPV} /\left((1+\mathrm{i})^{\mathrm{N}}-1\right)\right)
\end{aligned}
$$

IRR: i such that

$$
\sum_{n=0}^{N} B_{\mathrm{n}} /(1+\mathrm{i})^{\mathrm{n}}=\sum_{n=0}^{N} C_{\mathrm{n}} /(1+\mathrm{i})^{\mathrm{n}}
$$

where:

$\mathrm{n}=$ year number

$B_{n}=$ benefit in year $\mathrm{n}$

$C_{n}=$ cost in year $\mathrm{n}$

$i=$ annual discount rate

$N$ = lifetime of project or rotation length

Net present value is generally recommended as being the preferred criterion in most finance and forest economics textbooks (Brealey et al. 2008, Klemperer 2003, Wagner 2012).

Net present value is particularly useful with relatively short-term forestry investments, such as fast-grown species in the southern hemisphere. It probably represents the longest time horizon that investors might have-say 5 to 20 years. Land expectation value is the extension of this approach into perpetuity for long-lived forestry investments of unequal time lengths, and also is termed the Faustmann formula, or soil expectation value. For forestry investors who can clearly determine their discount rate, NPV and LEV provide the best means to maximise profits, given a fixed, known area of land. Selecting those projects with the highest total LEV for a given limited land area will generate the most net returns for a fixed amount of capital.

Internal rate of return is generally considered a theoretically inferior criterion, but its use persists for many practical reasons in the finance and forest economics literature and applications. Internal rate of return is easy to understand, explain, and compare with other investment metrics. As noted above, Sedjo (2001) relied on IRR in comparing timber investments a decade ago in a similar analysis. Often owners do not know their discount rate, so IRR provides a means of comparing investments intuitively with the implied cost of capital. Internal rate of return avoids problems of project scale or length in making comparisons. For example, large timber investment and management organisations (TIMOs) and Real Estate Investment Trusts (REITs) may make investments ranging from a few million dollars to hundreds of millions of dollars. The LEV is not very useful in comparing these but the IRR is.

Much of the theoretical finance literature uses annual returns from different investments, including timber, for comparing risk and return, Capital Asset Pricing, and portfolio optimisation (e.g., Redmond and Cubbage 1988, Cascio and Clutter 2008, Mei and Clutter 2010). Internal rate of return is often used as a proxy for annual returns in the forest finance literature, making it comparable other asset class analyses. So use of annual returns and IRR are widely accepted even in theory for finance applications. Internal rate of return also remains in wide use in the forest products industry. Hogaboam and Shook (2004) found that $52 \%$ of forest products firms used IRR 
as their preferred capital budgeting criteria, versus only $18 \%$ who preferred NPV. Last, IRR or annual rate of return surely is the most common metric referred to in timber investment conferences and by TIMOs and REITs (e.g., Leal 2008).

We used a uniform $8 \%$ real discount rate to estimate returns for all species in all countries. We did it this way because the exact discount rate for more than a dozen countries over a decade is not possible to determine. We did survey discount rates used in forestry investments as part of the research, and they ranged from as low as $6 \%$ in the northern hemisphere to $15 \%$ in the southern hemisphere. Thus, we selected $8 \%$ in 2005 , and have kept that as the baseline for every year the research data have been collected. This fixed discount rate allowed all investments to be compared on the same basis, without the cost of land, for the entire period. This discount rate and annual timber investment cash flows were then used to estimate the net present value for one forest rotation, the land expectation value (or what one could pay for land based on an infinite number of exactly identical forest rotations, costs, and prices) and the internal rate of return.

Positive NPVs and LEVs indicate that a timber investment would be an acceptable option in order to receive an $8 \%$ annual rate of return. Conversely, negative LEVs would indicate the amount one theoretically would have to be paid in order to obtain an $8 \%$ annual rate of return. In practice, of course, forest landowners actually just have to accept rates of return less that $8 \%$ often, and do not get additional payments. However, this approach standardises timber investment comparisons across countries and for a decade of analyses. Greater NPVs, LEVs, IRRs indicate preferred investments based on these financial criteria.

We also collected data on forest land prices for most countries in 2011. These data allowed us to compare estimated land prices with the calculated LEVs, which in theory should provide a measure of land price. However, land prices often exceed the estimated present value of their discounted returns, because the anticipated increase in land rent is greater than the calculated rents. This approach also allowed us to compare the theory of LEV land price calculations with the actual market prices in countries where data was available. Financial, political, social, export, and environmental risks also affect these investments, which we analysed as well.

The data collection and entry were standardised by use of a common spreadsheet with appropriate cells for each researcher to fill in with information for their species/country. The spreadsheet was a template with cells for species, country, management costs, timber productivity, and timber returns, which were then used to calculate various capital budgeting metrics. The template is available as supplementary information (see Additional File 1). The approach in the template and its capital budgeting formulas are described in detail (in Spanish and English) by Cubbage et al. (2011, 2013). Several researchers have adapted the template to work best in their situation, such as: modifying timber prices from a stumpage basis to a mill basis; adding more product classes; or adding more analyses of land or other factors.

In a few cases, several researchers worked in the same country, although not always with the same species. Where more than one individual was familiar with a species, a synthesis of data and inputs was used and reviewed by the relevant researchers for that country. In addition, all the spreadsheets and calculations were reviewed by the lead author and any anomalies were noted and verified or rectified through an iterative process with lead researchers in each country. Subsequent analyses of the effects of land, regulations, and productivity on the various metrics studied were performed after the base results were established for each country. Data for these additional analyses were obtained from just a few key countries in the Americas to date. These analyses were performed by just calculating the changes in NPV for one rotation, since including land prices and other factors for perpetuity would be too complicated, and unnecessary for just estimating the incremental effects of the sensitivity assumptions on returns. However, we calculated the NPV of four Eucalyptus spp. pulpwood rotations in Brazil for a total of 24 years, in order to make it a comparable NPV period to the other species.

Summaries of comparative macroeconomic, country risks, and ease of doing business were made for a broader set of countries since the data were readily available from agencies such as the Belgium Export Credit Agency (ONDD) (2011), the Organisation for Economic Cooperation and Development (OECD) (2011) and Standard and Poor's (2011). Then the final tables of inputs, costs, yields, and investment returns were assembled and analysed to examine trends for each year that this benchmarking exercise was performed-2005, 2008, and 2011.

The results include an overview of the economic factors in each country and the timber investment returns. However, despite having investment return data for many countries and years, a statistical cross sectional/ time series/panel data analysis was not possible, or at least not wise. The benchmarking data are still too different among years and countries for sound statistical analysis, and there are missing countries and species in each year.

In addition to the timber investment returns, it is useful to have some benchmarks for other asset classes. Finding global benchmarks is difficult, but a useful 
reference by Damodaran (2012) summarises annual returns on USA stocks, short-term Treasury (T) bills, and long-term Treasury bonds. An Inflation Calculator (2012) provided a means to calculate real returns similar to those we calculated for timber investments. We estimated periodic returns for stock and bond returns for the same initial years as the timber investments-2005 to 2011; 2008 to 2011; and for 2000 to 2011.

We also calculated the net effect of stock appreciation or depreciation on timberland investments as an index assuming that one started with a $\$ 100$ million investment. This is important, because a percentage investment loss has a greater effect than a percentage investment gain-the loss reduces the base, and thus any gain is calculated on that smaller base. Many investors also seek dividends or annual payouts from their portfolio in addition to capital appreciation. To simulate the effects of a constant payout on investment returns and capital appreciation, we also assumed that the average annual stock returns paid a dividend from their annual gains or losses at a fixed rate of $5 \%$ ( $\$ 5$ million) of the initial $\$ 100$ million investment value during the 2000s. This is a minimum hurdle rate often sought by investors, and achieved approximately by the better timberland investments.

\section{Results}

The key inputs and outcomes for the analysis of the 40 timber investment management regimes and capital budgeting returns in 2011 are summarised in Additional File 2. The trends in LEV and IRR for key countries where we have collected data over time are summarised in Additional File 3. The sensitivity analysis of these returns for the effects of land prices, productivity rates, and environmental regulations for the key countries in the Southern Cone of South America and for the United States are summarised in Additional File 4. Some selected risk estimates as of 2011 for the countries analysed are summarised in Additional File 5. In total, these provide a wealth of information about comparative timber investment returns over the seven year period. The analyses of US stock and bond returns since 2000 are summarised in Additional Files 6 and 7 respectively.

\section{Timber investment returns, 2011}

The results indicate that excluding land costs, returns for exotic plantations in almost all of South America-Brazil, Argentina, Uruguay, Chile, Colombia, Venezuela, and Paraguay-were substantial, and in China as well. Eucalyptus species returns were generally greater than those for Pinus species in each country, with most having IRRs of $15 \%$ per year or more. Internal rates of return for Pinus species in South America were generally closer to $10 \%$ than $15 \%$. Internal rates of return for plantations of coniferous or deciduous species in China, South Africa,
New Zealand, Australia, Mexico, and the United States, were lower still (ranging from 5\% to 12\%) but were still attractive.

The greatest amount of information for the countries in this study was available for the year 2011, as the set of co-authors expanded over time. In that year, all of the species in Latin America had positive LEVs at the 8\% discount rate. The LEVs in Australia and New Zealand were positive for Eucalyptus spp. and slightly negative for Pinus spp., indicating they had IRRs slightly less than $8 \%$. The USA had the lowest LEVs-all were negative-and IRRs of about $5.3 \%$ to $7.7 \%$. These base investment returns in 2011, excluding land costs, favour afforestation in South American countries, which have fast growth rates and reasonable timber prices. Other developing countries and the Asia-Pacific region had lower rates of return, with perhaps the exception of China, but still were attractive, based on the still prospering regional economy in Asia. North America, especially the US South, had the lowest calculated rates of return due to modest growth rates and low timber prices.

The LEVs calculated using the Faustmann formula (Equation 2) indicate the price that one could pay for land per hectare and still receive an $8 \%$ annual, real rate of return. A positive LEV indicates that one could pay that amount for the land; a negative LEV indicates that one cannot earn an $8 \%$ annual rate of return; the internal rate of return is less than $8 \%$. The more negative the LEV, the more money that landowners would lose at an $8 \%$ discount rate, and the lower the internal rate of return. In practice, LEVs do not specifically estimate the value of the land; they just indicate the potential returns assuming perfect knowledge and perfect capital markets existed, the discount rate was correct in all locations at all times, and all the costs and prices were estimated exactly. Our calculated LEVs then indicate that if one can buy land for less than LEV, one could still receive an $8 \%$ annual rate of return. But if one had to pay more per ha than the LEV, timber-land investors would receive less than an $8 \%$ rate of return. Investors of course would like to find regions that have large LEVs, but cheap land, to maximise their profits.

The same general rankings occurred among countries and species with IRRs as with LEVs. Brazil had the highest LEVs, and other South American countries also performed well. However, these high LEVs also may be not much different, or even less, than the price of land in Brazil, so the net IRRs in Brazil may be fairly close to $8 \%$, not including the costs of environmental regulations. The Brazil LEVs of about $\$ 4800 /$ ha for Pinus taeda in Santa Catarina and $\$ 6300 /$ ha for Eucalyptus species in Sao Paulo state were pretty close to the price of land for forests in those regions in 2011. However, land prices probably have increased since then due to competing uses for increasingly valuable 
crops of soybeans, sugar cane, or corn. So, it will be harder for investors to buy land in southern Brazil and achieve an $8 \%$ IRR/positive LEV by growing trees. Thus, they have moved to more northern or inland locations, such as Mato Groso de Sul, Miranão, Piaui, or Tocantins, where land prices are cheaper, although timber productivity, markets, and good timber prices are less assured.

The LEVs at the 8\% discount rate in 2011 in other South American countries also often approximate the prices of land. Argentina and probably Paraguay had LEVs somewhat greater than the price of land. Chile and Uruguay had land prices somewhat greater than LEVs at $8 \%$, but still close. Land expectation values in temperate forests, however, were generally close to zero or even negative. This means that for new investors who have to buy land, they cannot achieve an $8 \%$ IRR. The US South had one of the lower returns, but New Zealand and Australia also had low rates of return, especially for new investors who would need to buy land.

These moderate differences between the LEV values at $8 \%$ and the estimated land prices reveal the weakness of relying on the Faustmann formula/LEV too narrowly. There are many factors that determine the actual land price everywhere, including expected annual or future returns, land price appreciation, scarcity and competition with other land uses, the discount rate, and demand. An LEV only captures a static set of input costs and output prices at a given discount rate, and is not dynamic enough to capture all market information and future expectations. Instead, it provides a good criterion for comparing different management regimes on a given tract of land, or comparative potential returns among species and countries with current forest plantation management, productivities, costs, and returns.

\section{Trends in timber investments}

The trends in investment returns during the period from 2005 to 2011 were compared with the findings from Cubbage et al. $(2007,2010)$ for investments in 2005 and 2008. These trends varied unpredictably by country (Table 2). The LEVs and IRRs in Brazil increased consistently throughout the period, which seems to mirror the large domestic and export demands, and the rapidly expanding Brazilian forest products sector. Argentina returns increased from 2005, and peaked in 2008. Internal rates of return in Chile decreased slightly during the period, probably reflecting the depressed world economy where they export most of their product. This also was true in Colombia, although for less apparent reasons. Investment returns in Venezuela seemed to be lower in 2011 than in 2008 , but the estimates were difficult to make due to high inflation and large fluctuations in exchange rate, so not much can be concluded from the three-year trends provided here.
The Uruguayan market is almost entirely dependent on exports, which probably caused the decreased returns from 2005 to 2011. New Zealand and China also had slightly lower IRRs in 2011 than 2008. The US South fared the worst with timber investment returns based on current costs and stumpage prices decreasing significantly from 2005 to 2011 . This situation obviously reflects the poor sales and prices of timber during the USA economic recession and enduring housing slump. The US Pacific Northwest actually had stable investment returns, probably due to better saw-timber prices and exports to China in 2011.

Note that the timber investment returns were relatively comparable to those cited by Sedjo (2001) for the countries in South America based on 1990 prices. However, the rates of return for the temperate forest regions of the US South and Pacific Northwest, South Africa, and New Zealand declined since his research. This does confirm common feelings that timber investment returns in the developed countries studied have been worse in the 2000s than in the 1990s. These returns also were considerably less than the historical USA NCRIEF returns through to 2005 as reported by Cascio and Clutter (2008).

\section{Effects of land prices, environmental protection, and higher productivity}

The results of the analyses of the effects of land prices, environmental protection, and higher productivity and timber prices are summarised in Additional file 4. Each of these variables were analysed at the typical land purchase price and environmental reserve requirements, or likely increases in timber growth rates. The directional effects of these factors are obvious. Buying land for environmental protection requirements reduces investment returns; better timber productivity and prices increase returns. The magnitude of these effects differs by country and by each factor, however, which is the key to net returns.

With the addition of land costs alone, the IRRs for the key species in the Southern Cone countries of Argentina, Brazil, and Uruguay approach $8 \%$ rather than $15+\%$. Brazil has IRRs that just exceed $8 \%$ (at about $8.2 \%$ and $8.3 \%$ ), while Argentina and Uruguay had returns of $7.8 \%$ and $7.3 \%$, respectively. The addition of land costs dropped the U.S Pacific Northwest returns to 5.7\%, and the US South returns to $2.6 \%$. It is interesting to note that an independent timber-land investment analysis by a US forest consultant (Thomas 2012) produced a value of $2.8 \%$ IRR for southern timber investments, which was very close to the value calculated in the present study although he used a slightly lower $\$ 2500$ per hectare land cost assumption.

Leal (2008) reported estimated annual investment rates of return for Brazil in 2008 including land, which were greater than those found in our research. He reported the lowest rates of return for lower risk investments for 
traditional investments in southern Brazil (10\% to 15\%), such as those that we calculated for Pinus and Eucalyptus species. He projected that adjacent expansion areas farther north would have higher rates of return (14\% to $18 \%)$. Frontier areas in the north of Brazil would have returns of $15 \%$ to $19 \%$; and that the Amazon could have returns of $10 \%$ to $30 \%$. However, these greater potential returns would carry more risk.

The countries in our analysis have varying legal requirements on forest land use, ranging from requirements for legal reserves in Brazil through use of buffers around streams in most countries to use of best management practices in the US South. Of the forest land area available, regulations effectively take out about $15 \%$ of the productive land base in the US Pacific Northwest to up to $50 \%$ of the productive land bases in Brazil (Additional File 4). We assumed that a share of all land purchased would be inoperable due to terrain and environmental restrictions, and that one would have to pay the same full price for that land as for productive land.

There would be no timber production at all on the areas affected by environmental regulations, resulting in a complete loss of income from the affected areas. This would then reduce the net returns for the entire property in proportion to the area lost. One would still have to buy the land in order to establish the plantation, but have no benefit from doing so from the affected hectares, although there were no added management costs others than taxes, of course. This loss of useless hectares in a purchased property would decrease net returns substantially.

Our estimates of land costs for areas that have complete environmental restrictions are imprecise. Land costs of $\$ 3000$ per hectare in the USA include an average mix across all land. In Brazil and Argentina, one probably can pay less for land that has absolute prohibition of forestry activities, but this amount is not clear. This fact would tend to make net rates of return with land costs in Brazil and Argentina somewhat higher than we calculated, but so indeterminate that our assumption of one base forest land price in each country was best.

The costs of reserving a share of the land base for environmental protection alone on already owned lands did not decrease investment rates of return as much as the purchase of the land did at prevailing rates in each country, generally only decreasing the IRRs by one or two percentage points. This is based on the assumption that you already own your land, and you do not need to pay to prepare the site nor to plant, and manage a stand, so the loss of a share of that land is not a large opportunity cost compared with buying new land.

However, coupling environmental protection requirements in each country with land purchase costs dropped all the IRRs to $5.4 \%$ (Pinus spp.) to $4.7 \%$ (Eucalyptus spp.) in Brazil and Argentina and the US Pacific Northwest (5.4\%), and to $2.1 \%$ in the US South (Pinus spp.). In some of these countries, returns decreased even further due to the additional amount of land that would need to be withdrawn from production due to environmental constraints. Higher yields and prices had the opposite effect to the above, and improved the returns in the Southern Cone countries the most. Without land costs, IRRs with improved productivity ranged from $18 \%$ to $37 \%$ in the Southern Cone, and were $7 \%$ and $8 \%$, respectively, in the US South and Pacific Northwest. Including all the factors of land costs, environmental protection requirements, and potential productivity increases, the IRRs were not that different among the Southern Cone countries (5.8\% to $6.5 \%)$ and the US Pacific Northwest (6.0\%), although the South still lagged behind noticeably (3.0\%).

\section{Investment risk and ease of doing business}

Key macroeconomic or political factors that affect country investments are summarised in Additional File 5. The OECD Export Risk ratings and the ONDD Political Risk, and ONDD Risk of Expropriation ratings all measure country risk with a low of 0 or 1 (lowest risk), and high of 7 (highest). These data are readily accessible, unlike our timber investment returns estimates, so other key forestry countries are also listed for reference. These data confirm the impressions that one might have about relative country-level risk, but make the gradations more clear. Australia, Chile, New Zealand, and the United States had the best risk ratings, as the most stable OECD countries. Of the non-OECD countries, Brazil, China, Mexico, and South Africa had the best ratings, of about 3. Colombia, Indonesia, and Uruguay fell in the next tier, with a common rating of about 4 . Paraguay was in the next group, largely alone with political and export risks of a 5, but less expropriation risk, perhaps based on its long history of private ownership. Argentina, Ecuador, and Venezuela ranked last, with a value of 7 for most risk ratings. Each of these countries has nationalised some private industry, including the nationalisation of some forest land in Venezuela.

The Standard \& Poor's foreign risk ratings divide countries between those termed "Investment Grade" (BBB- or better) and those termed "Speculative Grade" ( $\mathrm{BB}+$ or less). Thus, countries such as Australia and Canada and Finland rate best (AAA); New Zealand and USA are one step below them (AA+). Other major forest plantations countries at Investment Grade include China, Chile, South Africa, Brazil, and Colombia. Brazil, Colombia and Peru were all just upgraded to this level in 2010 and 2011. Costa Rica, Indonesia and Uruguay have Standard \& Poor's ratings of BB or better, and also have been upgraded recently. In terms of new forest 
plantations, Uruguay has received investments far above its nominal Standard \& Poor's and risk ratings, perhaps because of its perceived low corruption and high literacy/education levels.

The World Bank's "Ease of Doing Business rankings" and "Number of Days to Start a Business" estimates do not favour Latin America countries. Out of 174 countries, Venezuela is almost the worst in the world. Indonesia, Ecuador, Brazil, Costa Rica, Uruguay, and Argentina all are in the lower third of the countries in the world for Ease Doing Business, saved only by the even worse record of most African countries. Similarly, they all take many Days to Start a Business, and conversations with forestry colleagues suggest that these are optimistic estimates for land investments. New Zealand, Colombia, Chile, China, and the developed OECD countries fare well on the Number of Days to Start a Business, and are in the upper half to best in the world on Ease of Doing Business.

Several countries in Latin America are also becoming more inimical to foreigners buying land. Due to limited available land and loss of local owners (e.g., Uruguay); land purchase by the government of China (e.g., Brazil); or massive purchases by rich foreigners (e.g., Chile, Argentina), each of the Southern Cone countries has either restricted purchase or is considering doing so. In Brazil in 2010, the Attorney General volunteered a new opinion that the Constitution effectively restricts direct future foreign ownership of agricultural and forest land. Various vehicles have been proposed or used to bypass this ruling, and indeed many believe that it is an incorrect interpretation of the Brazilian Constitution. However, the ruling was explicitly restated in 2011, casting doubt on rural-land investments occurring without having a majority Brazilian investor. This situation is causing severe problems and deterring investments.

In December 2011, Argentina passed a "Ley de Tierras" (Land Law), which prohibited direct foreign ownership of land of more than 1000 hectares. Uruguay has not prohibited foreign ownership, but its president has opined against building any more large pulp mills in the country. However, the country still granted tax exemptions for a second new pulp mill in 2012. Chile is not restrictive per se, but has little available land for forest plantation investments, and the two major forest products firms do not want to lose their core land base to new investors. In addition, the recent increases in agricultural commodity prices have caused large pressures for many good forest sites to be converted to crops throughout the world. Despite concerns in other countries, Colombia on the other hand is encouraging foreign direct investment, and Ecuador is actively seeking to make major new forest plantation investments.

\section{Comparative financial asset investment returns}

Statistics for comparative USA equity and debt investments for 12 recent years that terminate in our last timber investment calculations are summarised in Additional File 6. The annual returns for stocks for that period are also graphed in Figure 1. They indicate that U.S equity and debt returns since 2000 have varied considerably, and differ depending whether one is calculating equity (stock) or debt (T-bills and T-bonds) and using nominal (with) or real (without) inflation. We calculated annual US stock returns for three different time spans (2000-2011; 2005-2011; and 2008-2011), since results may vary by the starting and ending dates.

Based on these three periods, the highest average annual stock returns were $4.6 \%$ per year with nominal inflation, or $2.1 \%$ in real terms. The best T-bill returns were worse, at $2.3 \%$ nominal, or $-0.2 \%$ real. The best $\mathrm{T}$-bond returns were better at $8.4 \%$ nominal or $6.3 \%$ real. However, the worst periodic real returns were negative for stocks for two of the three periods and for bonds for all three of periods selected since 2000. Equity investments of stocks still comprise more than $75 \%$ of USA public investments, so should be considered the most relevant benchmark. In addition, the variability in stock returns was far worse than other assets in the 2000s, including timber-land returns as calculated here.

The calculations of indexed net returns on average USA equity investments since 2000 indicate that they have performed poorly (Additional File 7). At best, the nominal returns increased $17 \%$ from 2005 to 2011, but net real returns were $0 \%$ (remaining at $\$ 100$ million). The indexed value of real stock returns from 2000 to 2011 was $\$ 78$ million; from 2008 to 2011 was $\$ 83$ million. So in real terms, not one of the equity investments would even provide any capital appreciation during that period. American stocks performed much better in 2012 (13\%) and 2013 (29\%), but it remains to be seen if this is a long-term trend or shortterm fluctuations. Annual NCREIF timber returns were excellent from 1987 to 2005 (Cascio and Clutter 2008), but also dropped substantially after the global recession

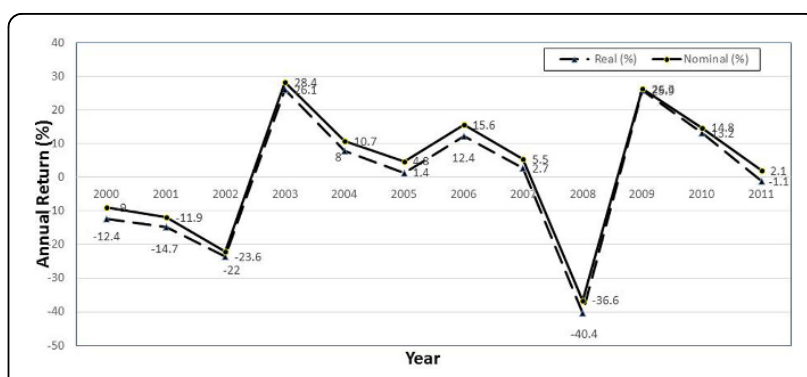

Figure 1 Annual nominal (with inflation) and real (excluding inflation) returns for US stock investments, 2000-2011. 
in 2008. They may have increased in the few years since the 2008 recession, but more slowly than stock market returns.

If one assumed a constant annual $5 \%$ payout ( $\$ 5$ million) of the initial $\$ 100$ million in addition to asset value changes, USA equity investments would be almost disastrous (Table 6; Figure 2). Nominal asset values would drop to an index of $\$ 34$ million for the 12-year period from 2000 to 2011 and to $\$ 74$ million from the four years from 2008 to 2011. Real asset values with a constant $\$ 5$ million payout would be much worse, dropping from $\$ 100$ million to $\$ 20$ million from 2000 to 2011, and $\$ 100$ million to $\$ 68$ million from 2008 to 2011. Again, our results indicate that timber-land returns, with about $2.5 \%$ to $7 \%$ real annual returns depending on the country, would usually maintain their base market price. In fact, land prices also have been stable or increasing in most countries, which would further increase total timberland investment returns for current investors.

\section{Discussion}

This research summarises global investment returns for key forest plantation countries in the world based on data from 2005 to 2011 . The data focus on returns to investments assuming that one owns land already, which would be typical for existing investors. It also adds a component to estimate returns with land costs for the key Southern Cone and USA regions and species.

We calculated and used three key capital budgeting metrics for measuring the financial performance of typical forest stands-NPV, LEV, and IRR. Each metric has merits for different applications. Net present value is a common and well understood discounted cash flow measure for project decisions, and is useful for short term investments of a similar scale and duration. Land expectation value extends NPV in perpetuity, and is useful for comparing timber investments of different lengths on the same area and (infinite) duration. Land expectation value also can be used to estimate the theoretical land value based on static management regimes, costs, and prices. Internal rates of

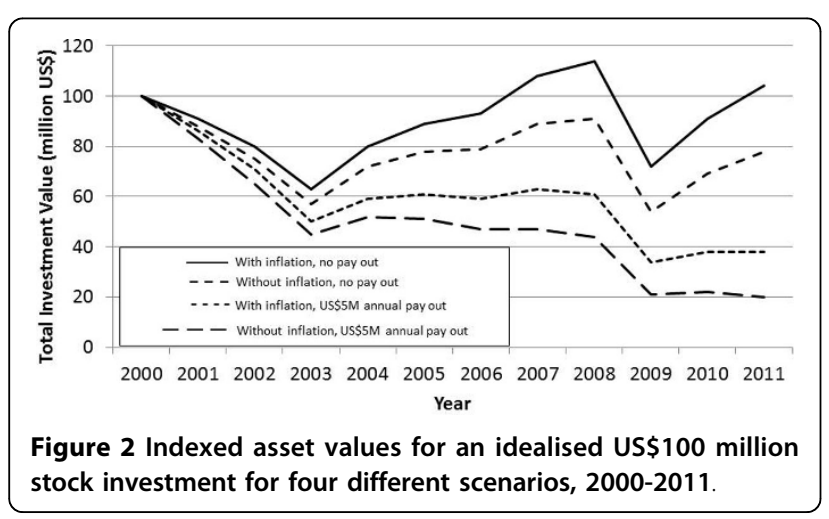

return or annual returns are used commonly in the finance literature, by forest-products companies, TIMOs, and REITs. It also is the most common metric used in the forest investment discussions, conferences, and comparisons with other assets. We have used IRR most frequently in the analyses conducted here because of its ease of understanding in comparisons. However the NPV and LEV are summarised in the tables as well for reference.

Our results indicate that the fast growth rates and higher reported timber prices drive the best timber investment returns because management costs were not much different among the different parts of the world. South America in general had the highest returns for existing investors, without the cost of land, and Brazil in particular was consistently the best country and improved during the period from 2005 to 2011. Opportunities for high rates of return (i.e. IRRs exceeding 10\%) and positive NPVs also existed for current landowners in each of the other Latin America countries studied. China also had a high IRR for Eucalyptus species, but this may be possible only in limited regions that have high timber prices. Also, finding available land for new investments is challenging. Furthermore, that land will have to be leased or rented either from the government or communities, which requires a large transaction cost and social-capital building.

Existing owners could achieve reasonably attractive plantation investments with real IRRs of about $7 \%$ to $12 \%$. Reasonable real rates of return also could be made in almost all of the other regions analysed, except the USA South, which had IRRs closer to 5\%. However, most of these investments could be similar to or better than the existing returns for other asset classes since 2000 . The returns we estimated here appear relatively conservative when compared with earlier research findings when both timber and stock markets were better, such as found by Leal (2008) or Cascio and Clutter (2008), which seems reasonable.

The results indicate that for purchasers of new land, the rates of return would be much lower-close to the $8 \%$ real discount rate, and closer to $6 \%$ with the costs of environmental protection considered. Environmental protection costs alone did not decrease returns much for present owners where land was a sunk cost. They mostly removed the land from production, but did not add more management costs. Higher productivity could compensate for some of the land and environmental costs, again raising most returns except the US South to the $6 \%$ to $8 \%$ IRR level.

Land costs are of course a key to determining net returns for new investors. We collected data on land costs at their typical sale price per hectare as of 2011. However, these are in considerable flux, based on some depression in timberland markets currently, and the reverse for agricultural land markets. In theory, the LEV 
data should provide a measure of land prices that is close to the estimated land prices, if the inputs and discount rate were correct. However, the LEV was only close to the estimated local land prices in about half the cases, indicating that more than discounted timber returns are contributing to forest land prices. This would suggest that LEV is more useful in analysing alternative timber growing returns and management regimes than for estimating the total value of land, which has many components other than timber growing potential alone.

In practice, land prices in the last decade increased rapidly in most of the countries examined, albeit for different reasons. The USA had increased timber-land prices with more demand, high rates or development for urban uses, and good timber prices up until the recession of 2008. Many of those factors were similar in South America and Asia, and land prices there have been further fuelled by rapid increases in prices for agricultural land, especially for soybeans, which can use converted forest land in some cases. In addition, given the Southern Cone financial crises in 2001 and 2008, investments in land were perceived as more secure than other investments.

The analysis also assumed that there would be a relatively fixed taxes and administration charge of $\$ 30$ per hectare per year for all the countries, stands, and species analysed, since there were no available data on costs of infrastructure development. This would suggest that the returns estimated would be most accurate for better developed regions, species and markets, which already largely have established roads, nurseries, land tenure policies, and markets. In areas where an investor must build their own infrastructure, nurseries, tree breeding programmes, and contractor network, the timber investment returns would certainly be less. Investors would need to do their pro forma analyses on the complete business model to determine the total costs and returns for a specific investment.

We also calculated returns for traditional equity and debt assets in the USA to compare with other timber-land investments. The returns for these assets in the 2000s were generally poor on average. There were some years with excellent returns, but almost as many with worse returns, which dragged the average annual returns to close to a $0 \%$ net gain during several periods during the 12 years. If one tried to provide a constant $5 \%$ payout based on the initial investment value, it would be disastrous, quickly depleting the initial investment value within a decade.

It is possible that one could receive higher equity investment returns than we calculated for the 2000s, either by picking more favourable starting and ending dates, or by actually making better than average investments. However, it difficult for any investment manager to consistently beat the stock market average; it may actually be easier to be a better than average forest manager since there are many owners who are not very actively engaged or have limited capital for investment.

The years of 2012 and 2013 had a significant bull market for US stocks, which will increase stock returns, at least in the short run. However, this also will make a new peak for stock returns, which has always been followed by an eventual stock market decline. One could also argue that annual returns in the 2000s were abnormally low, and will return to high levels experienced in the 1990s. However, the poor macroeconomic environment of much higher structural US and EU deficits and government debt, the European recession, and continued global unemployment do not lead to optimism for stable high equity or sovereign debt returns.

\section{Conclusions}

Overall, these results are encouraging in that they indicate the opportunity for reasonable but not unrealistic rates of returns in forest plantation investments in many parts of the world. All 40 timber investments had IRRs greater than $5 \%$ without land costs included although, in 8 cases, the IRR was less than $8 \%$, which made the NPV and LEV negative.

With land costs included, the IRRs and LEVs would be much lower. We had information on land prices for 34 cases, and 19 of those had LEVs less than the reported land cost in the region. Thus one could expect to make some profits with forest plantation investments by buying land and growing timber at an $8 \%$ discount rate in about half the cases, but one would have to accept a smaller IRR/discount rate in the rest of the cases.

The more temperate forests with slower tree growth rates do have lower rates of return, but are competitive with most other asset classes currently. These returns are comparable to or better than the stock market returns for the period, and do offer benefits of portfolio diversification as well as annual growth in value with the growth of the trees. Nevertheless, in the face of increasing land costs and somewhat depressed timber markets, especially in North America, forest investors will have to be better than average managers via maximising returns per unit of input in order to make attractive profits.

In order to achieve the highest rates of return at the stand level, new investors must choose countries with higher levels of political and investment risk, more difficulty in doing business, more environmental regulation, and higher transactions costs. In addition, the timber prices reported here for many countries are based on very thin timber markets-very few buyers and sellers-and are probably less predictable or assured than in the more developed markets such as the US South and Pacific Northwest. This timber market uncertainty in new regions 
may be offset in the larger countries such as Brazil and China where a substantial domestic timber demand exists, and that are less dependent on export demand and prices.

Many investors are being courted for new regions in Brazil, Colombia, Ecuador, Southeast Asia, or even Africa. Land costs are cheaper there, which can make returns better, but the development of timber markets really is conjecture, and apt to be linked to one or two major mills. Decades ago, many vertically integrated forest products firms and large investors bought forest land at much cheaper prices than currently available, and established forest plantations in each of the countries analysed here. Our analyses indicate that there are attractive returns for those old investments, not including the costs of the land in the analysis today. One challenge for those investors today is to decide whether to keep obtaining high rates of return on their forest investments assuming essentially no land costs-sunk costs from previous investments-or whether to sell their productive forest lands at high prices and to be converted to agriculture crop production. If they do sell, they would still need to obtain timber supply from other sources such as local out-growers or new TIMOs and REITs, or to close their forest products manufacturing facilities at those locations.

New forestry investors also can achieve reasonable rates of return in forest investments, but more in parity with reduced returns for most investments in the 2000s. These opportunities will be tempered by the challenge of extending smaller scale investments to new regions and new countries without the vertically integrated forest products manufacturing advantage. Pure timber-land investors will have to build their own forestry and maybe even some road infrastructure in new regions, so will have much higher administration and overhead costs than those we used in these calculations. They also must weigh the prospects for continued market expansion of forest products, and the competition with agriculture land, and concerns of target countries with limited land resources. Increased demand for land with increased population and development-so-called higher and better use (HBU) land-which we did not include in our calculations, will provide some opportunities for greater returns in the future as well. Finding the balance among investment returns, investment risk and difficulty, market opportunities, and willing host countries will continue to challenge and reward forest investors and managers in the 2010s.

The returns for other traditional assets indicate that the returns that we calculated for forestry investments, even with land costs and environmental constraints, are quite competitive. The forestry returns were also less variable (although we did not have enough time series data to calculate standard deviations). Furthermore, land prices for agriculture land have increased considerably, and forest land prices moderately throughout the world, which would increase forest investment returns. For example, the US South NCREIF (2013) timber-land price series from 2000 to 2012 indicates that up to half the total price appreciation has been due to land price appreciation, which would effectively double US returns we calculated here. Land price appreciation in South America and other parts of the world also has been rapid, with land prices actually being even greater than in the USA.

Investors will assess overall global market demand, local demand, and their effects on timber and land prices. The financial crisis of 2008 , leading to the USA and southern European housing market crash, has depressed saw-timber prices in most OECD countries, with only Asia escaping this trend so far. Local market demand has increased in the Southern Cone countries of Brazil and Argentina. Western South America has large populations but historically unstable macroeconomic factors; but they are improving, thus forestry investments might be more attractive in the future.

\section{Additional material}

Additional File 1: Global Timber Investments, 2011 - Calculation
Template
Additional File 2: Table 1. Plantation Investment Analysis Summary for
Selected Species and Countries, 2011
Additional File 3: Table 2. Trends in Plantation Investment Returns for
Selected Species and Countries, 2005-2011
Additional File 4: Table 3. Plantation Investment Sensitivity Analysis
Summary for Selected Species and Countries, 2011
Additional File 5: Table 4. Selected Risk Measurements for Major Forest
Plantation Investment Countries, 2011
Additional File 6: Table 5. Average Annual U.S.Investment Returns and
Asset Appreciation for Conventional Assets, 2000-2011
Additional File 7: Table 6. Net Indexed Asset Values for \$100 Investment
Based on U.S. Stock Returns

Competing interests

The authors declare that they have no competing interests.

\section{Authors' contributions}

Each author collected data for their country and reviewed various versions of this data and this manuscript at various stages of its development and presentation as speeches.

\section{Acknowledgements}

Thanks to the Southern Forest Resource Assessment Consortium (SOFAC) for partial funds for this research, as well as salary support from each organization for the contributing co-authors in the research effort.

\section{Declaration}

Publication of this supplement was funded by the New Zealand Forest Research Institute Limited (trading as Scion).

This article has been published as part of JOURNAL Volume 44 Supplement 1, 2014: Proceedings of the Third International Congress on Planted Forests. 
The full contents of the supplement are available online at http://www nzjforestryscience.com/supplements/44/S1.

\section{Authors' details}

'Fred Cubbage, Professor, Forestry and Environmental Resources, North Carolina State University, Raleigh, NC 27695-8008, USA. ${ }^{2}$ Universidad Nacional de Misiones (UNAM), Eldorado, Misiones, Argentina. ${ }^{3}$ Instituto Nacional de Investigación Agropecuria (INIA), Tacuarembó, Uruguay. ${ }^{4}$ University of Georgia, Athens, Georgia, USA. ${ }^{5}$ Universidad de la República, Montevideo, Uruguay. ${ }^{6}$ Universidad de Concepción, Concepción, Chile. ${ }^{7}$ ArborGen, Ridgeville, South Carolina, USA. ${ }^{8}$ Mason, Bruce, \& Girard, Inc., Portland, Oregon, USA. ${ }^{9}$ Abt Associates, USA. ${ }^{10}$ Universidade Federal do Paraná, Paraná, Brasil. "'Universidade do Contestado, Santa Catarina, Brasil. ${ }^{12}$ Universidade do São Paulo, Piracicaba, Brasil. ${ }^{13}$ New Zealand Forest Research Institute Ltd., New Zealand. ${ }^{14}$ Forestry Tasmanaia, Australia. ${ }^{15}$ Mondi Group, South Africa. ${ }^{16}$ Universidad de Asunción, Asunción, Paraguay. ${ }^{17}$ Comisión Nacional Forestal, México. ${ }^{18}$ TerraSource Valuation, Waxhaw, NC USA. ${ }^{19}$ North Carolina State University, Raleigh, North Carolina, USA.

Published: 26 November 2014

\section{References}

Binkley C: Preserving nature through intensive plantation forestry: the case for forestland allocation with illustrations from British Columbia. Forestry Chronicle 1997, 73(5):553-559.

Brealey R, Myers S, Allen F: Principles of Corporate Finance . New York: McGrawHill; 92008.

Carle J, Holmgren P: Wood from planted forests: A global outlook 2005-2030 Forest Products Journal 2008, 58(12):6-18.

Cascio AJ, Clutter MH: Risk and required return assessments of equity timberland investments in the United States. Forest Products Journal 2008, 58(10):61-70.

Cubbage F, Mac Donagh P, Sawinski Júnior J, Rubilar R, Donoso P, Ferreira A, Hoeflich V, Morales Olmos V, Ferreira G, Balmelli G, Siry J, Noemi Báez M, Alvarez J: Timber investment returns for selected plantation and native forests in South America and the Southern United States. New Forests 2007, 33(3):237-255.

Cubbage F, Koesbanda S, MacDonagh P, Balmelli G, Morales Olmos V, Rubilar R de la Torre R, Hoeflich V, Murraro M, Kotze H, Gonzalez R, Carrerro O, Frey G, Turner J, Lord R, Huang J, Macintyre C, McGinley K, Abt R, Phillips R: Global timber investments, wood costs, regulation, and risk. Biomass and Bioenergy 2010, 34(2010):1667-1678

Cubbage FW, Davis RR, Frey GE: Guía para la Evaluación Económica y Financiera de Proyectos Forestales Comunitarios en México. Documento de Trabajo, Forestal Latinoamericano. Washington, D.C.: Banco Mundial Región de Latinoamérica y el Caribe; 2011, Retrieved 18 January 2012 from http://www. profor.info/profor/knowledge/community-forestry-enterprise-competitivenessand-access-markets-mexico.

Cubbage F, Davis R, Frey G, Chandrasekharan Behr D: Financial and Economic Evaluation Guidelines for Community Forestry Projects in Latin America. Washington, D.C.: PROFOR \& the World Bank, Latin America and the Caribbean Region; 2013, Retrieved 21 February 2013 from http://www.profor.info/ knowledge/community-forestry-enterprise-competitiveness-and-access-marketsmexico.

Damodaran A: Returns for stocks, bonds, and T-Bills. 2012, Retrieved 2

December 2012 from http://pages.stern.nyu.edu/ adamodar/New_Home_Page/ datafile/histretSP.html..

Food and Agriculture Organization (FAO): Global Forest Resources Assessment, 2005. Rome: Food and Agriculture Organization of the United Nations 2007. Food and Agriculture Organization (FAO): Global Forest Resource Assessment 2010. Rome: Food and Agriculture Organization of the United Nations 2010, (FAO Forestry Paper 163)

Food and Agriculture Organization (FAO): State of the World's Forests, 2011. Rome: Food and Agriculture Organization of the United Nations 2011, Food and Agriculture Organization of the United Nations.

Hogaboam L, Shook SR: Capital budgeting practices in the USA forest products industry: a reappraisal. Forest Products Journal 2004, 54(12):149-158. Inflation Calculator: 2012, Retrieved 2 December 2012 from http://www. usinflationcalculator.com/inflation/historical-inflation-rates/.

Klemperer D: Forest Resource Economics and Finance. Blacksburg, VA, USA: David Klemperer; 2003.
Leal J: How to maximize gains and diversify risks in forest investments in Brazil. Presented at the Timberland Investing Latin America Summit. 2008, 3-4, São Paulo, Brazil. March 2008.

Mei B, Clutter M: Evaluating financial performance of timberland investments in the United States. Forest Science 2010, 56(5):421-428.

National Council of Real Estate Investment Fiduciaries (NCREIF): Retrieved 22 October 2014 from NCREIF timberland index. 2013 [http://www.ncreif.org/ timberland-returns.aspx].

Organisation for Economic Cooperation and Development (OECD): OECD Export Risk. 2011, Retrieved 22 October 2014 from http://www.oecd.org/tad/xcred/crecrc-historical-internet-english.pdf.

The Belgian Export Credit Agency (ONDD): OND/ NDD - Country risks synthesizing chart. 2011, Retrieved 16 March 2011 from http://www.ondd.be. Redmond $\mathrm{CH}$, Cubbage FW: Risk and returns from timber investments. Land Economics 1988, 64:325-337.

Sedjo RA: The role of forest plantations in the world's future timber supply. The Forestry Chronicle 2001, 77(2):221-225.

Sedjo R, Botkin D: Using forest plantations to spare natural forests. Environment 1997, 39(10):14-20. Standard \& Poor's: Country Risk ratings. 2011, Retrieved 23 May 2012 from http://www.standardandpoors.com/ratings/sovereigns/ratings-list/en/us/? subSectorCode $=39$.

Thomas M: Maybe it's time to look at timber growing through contrarian eyes. (F\&W Forestry Report No. 112) 2012, 1-2.

Wagner JE: Forestry economics: a managerial approach. New York: Routledge; 2012.

World Bank: Ease of Doing Business - Spreadsheet. 2011 a, Retrieved 22 October 2014 from http://www.doingbusiness.org/reports/global-reports/doing-business2011\%.

World Bank: Number of Days to Start a Business. 2011 b, Retrieved October 2014 from http://www.data.worldbank.org/indicator/IC.REG.DURS.

doi:10.1186/1179-5395-44-S1-S7

Cite this article as: Cubbage et al:: Global timber investments and trends, 2005-2011. New Zealand Journal of Forestry Science 2014 44(Suppl 1):S7.

\section{Submit your manuscript to a SpringerOpen ${ }^{\mathcal{O}}$ journal and benefit from:}

- Convenient online submission

- Rigorous peer review

- Immediate publication on acceptance

- Open access: articles freely available online

- High visibility within the field

- Retaining the copyright to your article

Submit your next manuscript at $\gg$ springeropen.com 